\title{
PEMURIDAN SEBAGAI IMPLEMENTASI AMANAT AGUNG YESUS KRISTUS
}

\author{
Serepina Yoshika Hasibuan
}

Sekolah Tinggi Teologi Mawar Saron Lampung

serepinahasibuan1991@gmail.com

\begin{abstract}
Discipleship is an important concept in Christianity, and the Great Commission is an important mandate for Christians throughout the ages. Both of these are the focus of research. The Great Commission is often associated with the Christian missionary movement but rarely with the discipleship movement. In its implementation, the Great Commission is realized by evangelism but ignores the aspect of discipleship. Therefore, the author analyzes Matthew 28:19-20 using a descriptive qualitative method with textual criticism, namely doing exegesis on the verse to understand the concept of discipleship in the Great Commission of the Lord Jesus Christ. Through this research, the writer finds that discipleship is the main aspect that must be targeted in implementing Christians' great mandate. In practice, discipleship goes through stages: reaching souls, baptizing them, and teaching God's commands.
\end{abstract}

Keywords: discipleship, Great Commission, Matthew 28:19-20

\begin{abstract}
Abstrak. Pemuridan adalah konsep penting dalam kekristenan dan Amanat Agung adalah mandat penting bagi orang-orang Kristen sepanjang zaman. Kedua hal ini merupakan fokus penelitian. Amanat Agung seringkali dikaitkan dengan gerakan misi Kristen tetapi sangat jarang dikaitkan dengan gerakan pemuridan. Dalam implementasinya, Amanat Agung diwujudkan dengan penginjilan tetapi kurang memperhatikan aspek pemuridannya. Oleh sebab itu, penulis menganalisis Matius 28:19-20 menggunakan metode kualitatif deskriptif dengan teknik kritik teks yakni melakukan eksegesis pada ayat tersebut untuk memahami konsep pemuridan dalam Amanat Agung Yesus Kristus. Melalui penelitian ini, penulis menemukan bahwa pemuridan adalah aspek utama yang harus menjadi target dalam implementasi mandat agung orang Kristen. Dalam pelaksanaannya, pemuridan melalui tahap-tahap yakni: pergi menjangkau jiwa, membaptis mereka dan mengajarkan perintah Tuhan.
\end{abstract}

Kata kunci: pemuridan, Amanat Agung, Matius 28:19-20

\section{PENDAHULUAN}

Esensi kekristenan adalah menjadi murid Kristus. Orang Kristen bisa saja mengakui diri sebagai Kristen tetapi belum menjadi seorang murid. Murid Kristus adalah orang-orang yang berkomitmen untuk mengikuti teladan 
BONAFIDE: Jurnal Teologi dan Pendidikan Kristen

www.jurnal.sttissiau.ac.id/Volume 2/Nomor 2/Desember 2021/hal.156-175

sang Guru dan menjadi serupa dengan Yesus Kristus. Keserupaan dengan Yesus Kristus dapat dilihat dengan pertumbuhan spiritual dan karakter seseorang yang memancarkan kemuliaan Tuhan (Gunawan 2020). Karena itu, penting sekali setiap orang Kristen menyadari bahwa eksistensi iman Kristen mengharuskan dirinya menjadi seorang murid Kristus.

Murid Kristus tentu memahami mandat Yesus Kristus yang tertulis pada Matius 28:19-20 yang sering dikenal sebagai Amanat Agung (Dwiraharjo 2019). Dalam melaksanakan Amanat Agung, banyak orang Kristen yang terperangkap dalam konsep sempit dari mandat ini misalnya memahami Amanat Agung sebagai perintah untuk menginjili (Belo 2019) orang atau membaptis orang saja (Yen 2019). Semakin banyak orang yang diinjili atau dibaptis, maka semakin puaslah mereka dan merasa sudah memenuhi Amanat Agung Yesus Kristus (Gandaputra 2021). Padahal prosesnya tidak boleh berhenti sampai di situ saja melainkan harus sampai pada menjadikan orang-orang yang dilayani tersebut sebagai murid Kristus yang sejati (Gunawan 2020).

Aspek pemuridan dalam implementasi Amanat Agung kurang mendapatkan perhatian dari orang Kristen pada umumnya. Amanat Agung diidentikkan sebagai perintah penginjilan kepada seluruh bangsa di dunia (Belo 2019). Berbeda lagi dengan pendapat George W. Peters yang dikutip oleh Surya dalam artikelnya, mengatakan bahwa fokus Amanat Agung adalah pengajaran (Surya dan Setinawati 2021). Penulis sendiri berpendapat bahwa fokusnya bukan penginjilan dan pengajaran melainkan pemuridan. Banyak misionaris yang tidak melanjutkan misinya ke arah pemuridan dan mencari solusi bagaimana orang- 
BONAFIDE: Jurnal Teologi dan Pendidikan Kristen

www.jurnal.sttissiau.ac.id/Volume 2/Nomor 2/Desember 2021/hal.156-175

orang yang sudah dilayaninya dapat menjadi 'guru' yang memuridkan sesama dalam sukunya. Sayangnya, jiwa-jiwa yang sudah mendengar Injil banyak juga yang tidak kuat memegang teguh imannya dan akhirnya kembali ke kehidupan lamanya karena tidak di-follow up lebih lanjut.

Penginjilan merupakan hal yang baik, apalagi jika diperhadapkan dengan frasa argumentatif, "lebih baik pergi memberitakan Injil daripada tidak melakukan apa-apa." Setiap orang Kristen memang wajib aktif menginjili orang-orang yang belum mendengar Injil Kerajaan Sorga. Akan tetapi, sekali lagi tidak boleh berhenti sampai di situ. Pemberitaaan Injil harus ditindaklanjuti dengan pembaptisan dan pengajaran yang dirangkum dalam proses pemuridan. Jadi, penginjilan harus berlanjut dengan pemuridan orang-orang yang baru percaya (petobat baru).

Secara eksegetikal, penginjilan hanya merupakan salah satu aspek yang terdapat dalam Amanat Agung. Penginjilan yang tidak dilaksanakan dalam konteks pemuridan merupakan kelalaian melaksanakan Amanat Agung secara benar. Penginjilan yang instan tidak akan menghasilkan murid Kristus karena pemuridan menunjukkan suatu proses. Sejarah gereja menjadi saksi penginjilan instan yang dilakukan gereja abad ke-2 dimana banyak orang menjadi Kristen bukan karena iman yang sejati melainkan demi ketenaran, kenyamanan dan kehidupan sosial yang lebih baik (Situmorang 2014). Berbondong-bondong orang memberikan dirinya untuk dibaptis tetapi setelah itu menjadi orang Kristen yang pasif. 
BONAFIDE: Jurnal Teologi dan Pendidikan Kristen

www.jurnal.sttissiau.ac.id/Volume 2/Nomor 2/Desember 2021/hal.156-175

Tuhan tidak menginginkan hal demikian. Analisis perintah Yesus Kristus pada Matius 28:19-20 jelas memberikan goal Amanat Agung yakni pemuridan bukan sekadar penjangkauan jiwa yang instan. Oleh sebab itu, penelitian ini bertujuan untuk menganalisis Matius 28:19-20 sebagai dasar implementasi Amanat Agung yang dilakukan dalam proses pemuridan para murid Kristus kepada seluruh bangsa di dunia ini.

\section{METODE PENELITIAN}

Metode penelitian yang dilakukan dalam artikel ini adalah metode hermeneutika dengan pendekatan teks. Penulis melakukan eksegesis beberapa kata pada Matius 28:19-20 dan menafsirkan ayat tersebut untuk memahami konsep pemuridan dalam Amanat Agung Yesus Kristus. Melalui analisis jurnaljurnal mutakhir dan buku-buku tafsir yang kompatibel, penulis menganalisis topik ini dan merangkumkannya secara kualitatif deskriptif.

\section{HASIL PENELITIAN}

Dari metode hermeneutika yang dilakukan pada penelitian Matius 28:1920 ditemukan bahwa pemuridan merupakan implementasi yang tepat dari Amanat Agung Yesus Kristus. Pemuridan dalam konteks Matius 28:19-20 ini dilaksanakan dalam tiga tahapan integratif yakni pergi untuk menjangkau jiwa baru, membaptis mereka dan mengajarkan mereka untuk melakukan perintah Tuhan Yesus Kristus. Tiga tahapan ini harus dilakukan secara simultan agar hasil pelipatgandaan dapat terwujud. Penjabaran selanjutnya dibahas di bawah ini.

\section{PEMBAHASAN}


BONAFIDE: Jurnal Teologi dan Pendidikan Kristen

www.jurnal.sttissiau.ac.id/Volume 2/Nomor 2/Desember 2021/hal.156-175

\section{Analisis Konteks}

Amanat Agung terletak di akhir tulisan Matius yang merupakan Injil pertama di Perjanjian Baru. Menurut Tenney, tujuan penulisan Injil Matius adalah untuk menunjukkan bagaimana Yesus dari Nazaret mengembangkan wahyu Ilahi yang telah dimulai dalam nubuat Mesias di PL (Tenney 2009). Meski berciri Yahudi, Matius mengakhiri kitabnya dengan Amanat Agung yang menjadi ‘jembatan penghubung' antara rekan-rekan Yahudinya dan para pengikut baru dalam konteks perwujudan misi Yesus Kristus bagi seluruh dunia (Tenney 2009).

Amanat Agung diberikan oleh Tuhan Yesus kepada kesebelas murid-Nya di bukit Galilea (Nainggolan 2014). Para murid berangkat dari Yerusalem menuju Galilea. Sebuah pertemuan yang sudah dijanjikan-Nya sebelumnya (Mat.26:32; Mrk. 14:28). Sebenarnya para murid sudah beberapa kali melihat Dia di Yerusalem, tetapi saat ini merupakan saat yang dinanti mereka sehingga mereka tidak ragu pergi ke sana sekalipun jaraknya jauh (Tjia, Schoot, dan Tjulianto 2008). Pada saat itu, kira-kira terdapat 500 orang (1 Kor.15:6) yang bersama kesebelas murid (Nainggolan 2014). Jadi, penampakan Yesus di Galilea lebih dapat digolongkan pertemuan umum daripada pertemuan pribadi yang seperti dilakukan-Nya sebelumnya (Tjia, Schoot, dan Tjulianto 2008).

Menjelang perpisahan-Nya dengan para murid, sebuah pesan penting disampaikan sebagai tugas utama kelanjutan pelayanan Tuhan Yesus di dunia yang akan segera diwariskan kepada para murid-Nya waktu itu (Arifianto, Triposa, dan Lembongan 2020). Sebuah mandat yang lebih tinggi dari yang lainnya karena itu disebut sebagai Amanat Agung. Karena posisinya yang tinggi, 
BONAFIDE: Jurnal Teologi dan Pendidikan Kristen

www.jurnal.sttissiau.ac.id/Volume 2/Nomor 2/Desember 2021/hal.156-175

maka dalam pelaksanaannya, Amanat Agung harus menjadi prioritas murid Kristus.

Sebagai sebuah pendahuluan, Ia mengatakan bahwa segala kuasa di bumi dan di Sorga telah diberikan kepada-Nya. Dari perkataan ini, Yesus jelas menunjukkan otoritas ilahi yang dimiliki-Nya (Gandaputra 2021) sekaligus merupakan jawaban pertanyaan yang dilontarkan para tua-tua Bangsa Yahudi dan imam-imam kepala (Mat. 21:23; Mrk. 11:28; Luk. 20:2). Otoritas yang disampaikan Yesus Kristus adalah karunia dari Allah Bapa yang berkuasa dan menjadi milik-Nya. Proklamasi kuasa ini juga menunjukkan bahwa Dia sendiri memegang kendali bukan hanya atas seluruh ciptaan yang ada melainkan atas seluruh alam semesta (Tjia, Schoot, dan Tjulianto 2008). Para murid tidak perlu ragu ataupun takut menjalankan Amanat Agung karena Yesus berkuasa. Dengan otoritas inilah, para murid Yesus menjalankan pemuridan ke seluruh dunia. Penugasan yang diberikan kepada mereka ditopang dengan kuasa-Nya atas segala sesuatu (Pfeiffer dan Harrison 2013).

Setelah menyampaikan otoritas-Nya, Ia mendeklarasikan Amanat Agung itu. Amanat Agung diberikan kepada para murid-Nya bukan berarti implementasinya hanya dilakukan oleh para rasul pada waktu itu saja melainkan oleh semua orang yang mengaku sebagai murid Kristus wajib melakukan mandat agung ini (Nainggolan 2014). Mandat tidak akan menghasilkan 'buah' tanpa ada action yang dilakukan oleh murid. Oleh karena itu, Amanat Agung perlu diimplementasikan secara nyata dalam kehidupan para murid. Action itu adalah pemuridan. 


\section{Bentuk Sintaksis}

Untuk menjelaskan esensi Amanat Agung yang berisi perintah menjadikan semua bangsa murid Tuhan, maka bentuk sintaksis di bawah ini membantu untuk memahami perintah Yesus Kristus tersebut.

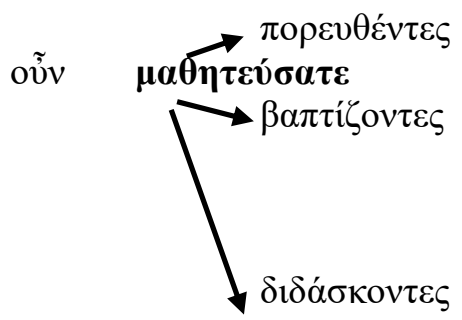

iঠov̀

$\dot{\varepsilon} \gamma \grave{\omega}$

Eijut

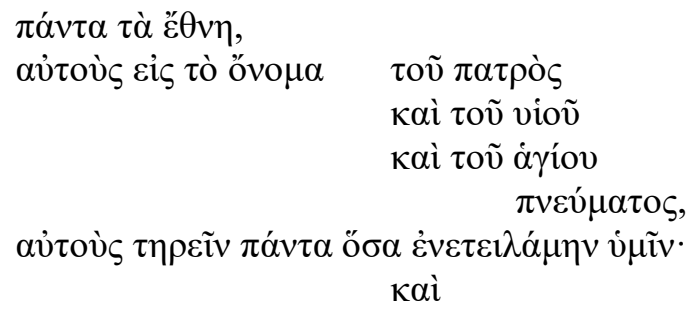

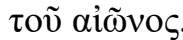

Bentuk sintaksis di atas menunjukkan bahwa kata kerja utama dalam Amanat Agung adalah matheteusate yang ditulis dalam bentuk imperatif sedangkan ketiga lainnya dalam bentuk partisip. Rangkaian sintaksis yang lebih lengkap dijelaskan melalui diagram Matius 28:19-20 dari Biblework 9, sebagai berikut: 
BONAFIDE: Jurnal Teologi dan Pendidikan Kristen

www.jurnal.sttissiau.ac.id/Volume 2/Nomor 2/Desember 2021/hal.156-175

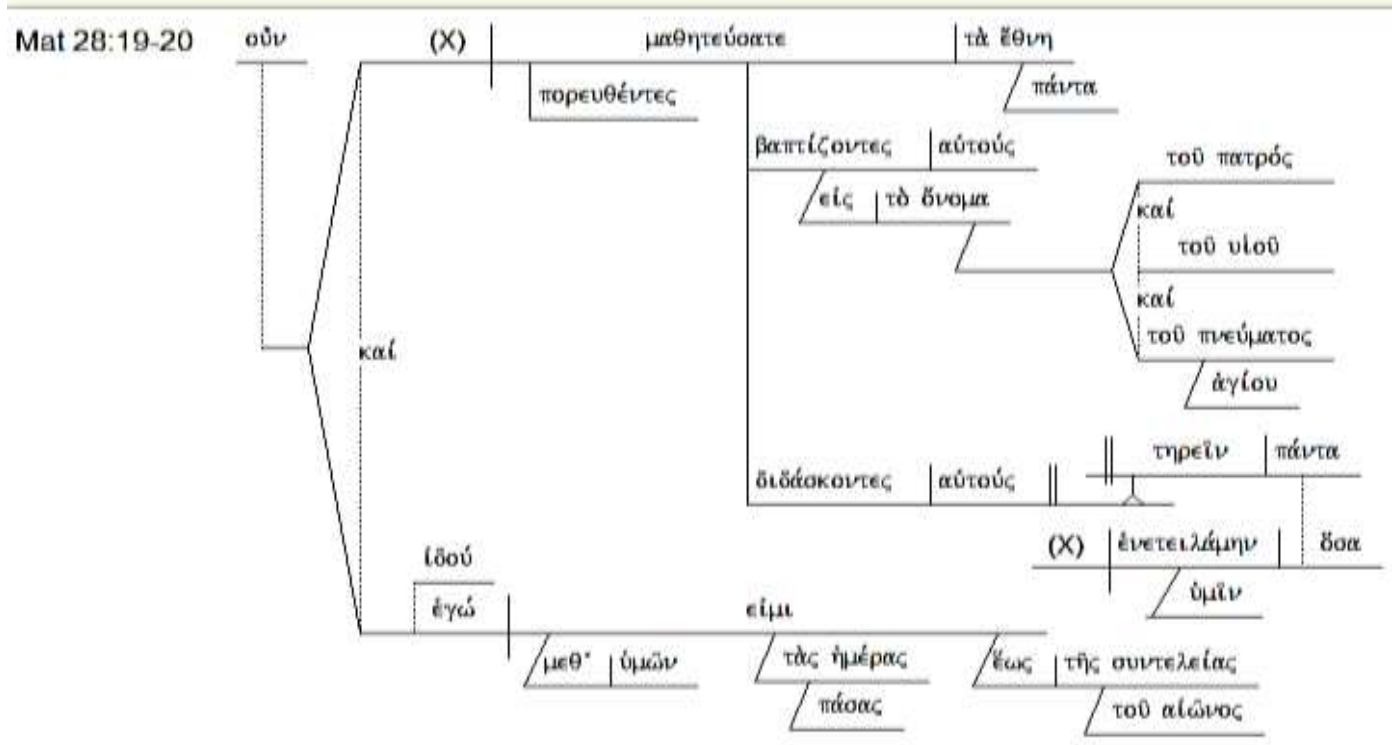

Gambar 1. Diagram teks Matius 28:19-20

\section{Analisis Teks}

Pada dua ayat yang dianalisis terdapat lima kata kerja yang dijelaskan dalam tabel di bawah ini.

\begin{tabular}{|c|c|c|c|c|}
\hline No. & Bahasa Asli & Kata Dasar & Bentuk & Terjemahan \\
\hline 1. & $\pi \circ \rho \varepsilon v \theta \varepsilon ́ v \tau \varepsilon \varsigma$ & $\pi о \rho \varepsilon v ́ о \mu \alpha \imath$ & Verb participle & (yang) pergilah... \\
\hline 2. & $\mu \alpha \theta \eta \tau \varepsilon v ์ \sigma \alpha \tau \varepsilon$ & $\mu \alpha \theta \eta \tau \varepsilon v ́ \omega$ & Verb imperative & Muridkanlah... \\
\hline 3. & $\beta \alpha \pi \tau i \zeta$ ov $\tau \varepsilon \varsigma$ & $\beta \alpha \pi \tau^{\prime} \zeta \omega$ & Verb participle & (yang) baptislah.. \\
\hline 4. & $\delta 1 \delta \alpha ́ \sigma \kappa o v \tau \varepsilon \varsigma$ & $\delta 1 \delta \alpha ́ \sigma \kappa \omega$ & Verb participle & (yang) ajarlah... \\
\hline 5. & cijut & 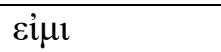 & Verb indicative & Aku adalah \\
\hline
\end{tabular}

Tabel 1. Analisis grammar kata kerja dalam Matius 28:19-20

Dari tabel di atas dapat diketahui bahwa tiga kata kerja ditulis dalam bentuk verb participle sedangkan dua kata kerja ditulis dalam bentuk verb imperative dan satu lagi dalam bentuk verb indicative. Kata kerja partisip merupakan verb adjective yang berfungsi menerangkan sifat kata kerja utama, sama seperti frasa preposisi (Mounce 2011). Meskipun ketiganya bernuansa imperatif, tetapi kata kerja partisip merupakan kata kerja pelengkap karena 
BONAFIDE: Jurnal Teologi dan Pendidikan Kristen

www.jurnal.sttissiau.ac.id/Volume 2/Nomor 2/Desember 2021/hal.156-175

fungsinya sebagai kata kerja yang menjelaskan 'sifat' dari kata kerja utama. Sedangkan, kata matheteusate ditulis dalam bentuk verb imperative yang menunjukkan fungsi yang lebih jelas yakni sebagai kata kerja perintah utama. Kata kerja partisip ditulis dalam konteks menerangkan kata matheteusate.

Pada ayat 20 juga terdapat kata kerja utama yakni eimi yang ditulis dalam bentuk verb indicative. Kata kerja indikatif merupakan bentuk kata kerja paling umum dalam bahasa Yunani yang menjelaskan sebuah tindakan yang biasanya terjadi pada waktu sekarang (Mounce 2011). Dalam bentuk yang lengkap kata ini juga mengandung kala present yang bukan hanya menyatakan waktu sekarang, tetapi aspek yang terus menerus. Aspek terus menerus ini justru lebih penting diperhatikan saat penafsiran (Mounce 2011). Tindakan yang dilakukan secara kontinu. Dengan demikian, Dia adalah Yesus yang senantiasa / terus menerus menyertai para murid.

\section{Murid yang Memuridkan}

Menjadi seorang Kristen berarti menjadi seorang murid Kristus. Sebagaimana makna kata Kristen adalah pengikut Kristus, dan murid adalah seorang yang mengikuti Sang Guru (Situmorang 2021), maka orang Kristen adalah murid Kristus yang senantiasa mengikuti Sang Guru baik dalam iman, karakter, dan pola hidup. Guru merupakan model yang ditiru olehnya.

Seorang murid Kristus perlu memahami tugasnya sebagai murid. Amanat Agung berisikan tugas seorang murid untuk menjadikan semua bangsa murid Kristus juga. Murid yang menciptakan murid 'baru'. Terdapat prinsip pelipatgandaan dalam frasa ini. Proses pemuridan ibarat proses 'kloning' yang 
BONAFIDE: Jurnal Teologi dan Pendidikan Kristen

www.jurnal.sttissiau.ac.id/Volume 2/Nomor 2/Desember 2021/hal.156-175

mana murid Kristus menciptakan murid baru yang memiliki sifat, karakteristik dan kualitas yang sama dengan murid hasil didikan Tuhan Yesus sendiri. Alkitab menerangkan buah pertama Amanat Agung dalam Kitab Kisah Para Rasul yang menceritakan perjalanan panjang pemuridan yang dilakukan oleh para rasul. Indikator pemuridan Kristen dapat dilihat dalam Kisah Para Rasul antara lain: mereka melayani bersama (Kis. 6:7); fokus pada pemberitaan Firman (Kis. 6:2); berani mempertanggungjawabkan iman walapun beresiko (Kis. 9:1); peka dengan suara Tuhan (Kis. 9:10); suka berbuat baik dan memberi sedekah (Kis. 9:36); mengajar banyak orang (Kis. 11:26); penuh dengan Roh Kudus (Kis. 13:52); dan bertekun dalam iman (Kis. 14:22).

Tuhan Yesus bukan menginginkan murid yang pasif melainkan murid yang menjalankan tugasnya, mampu memuridkan orang lain sehingga mereka pun menjadi murid baru. Dari penjuru-penjuru dunia ini akan muncul petobat-petobat baru yang diproses untuk menjadi murid yang militan menjalankan Amanat Agung kepada orang lain lagi di sekitarnya. Semakin banyak yang menjadi murid baru maka sangat mungkin semua bangsa akan menjadi murid-Nya. Melalui pemuridan, murid-murid bukan hanya bertambah tetapi juga bertumbuh (Hutagalung 2020).

Dalam menjalankan tugas pemuridan, maka murid perlu memahami apa itu pemuridan. Bagaimana Tuhan mempersiapkan murid-murid dan bagaimana Tuhan juga memperlengkapi mereka? Persiapan yang dilakukan Yesus kepada para murid yang siap memuridkan adalah memberikan mereka kuasa, seperti kuasa yang ada dalam diri-Nya. Murid dipersiapkan dengan kuasa ilahi untuk 
BONAFIDE: Jurnal Teologi dan Pendidikan Kristen

www.jurnal.sttissiau.ac.id/Volume 2/Nomor 2/Desember 2021/hal.156-175

berani memberitakan, membimbing dan mengajar orang lain yang siap menjadi murid. Kuasa yang sama ada dalam diri kita sebagai murid Kristus masa kini. Kuasa itu mendorong kita untuk memberitakan, menjangkau, membaptis dan mengajarkan orang-orang segala yang diperintahkan Tuhan dalam firman-Nya.

Selain itu, murid-murid juga diperlengkapi dengan janji penyertaan-Nya yang sempurna. Sekalipun sesaat lagi waktunya Ia naik ke Sorga, tetapi Yesus Kristus berjanji Ia tidak meninggalkan mereka. Ia tetap berada di dalam diri para murid untuk menyertai mereka hingga kesudahannya karena Dia adalah Immanuel. Jadi, cara mempersiapkan, melaksanakan dan memperlengkapi para murid sudah tertuang dalam Amanat Agung-Nya.

\section{Pemuridan sebagai Implementasi Amanat Agung}

Berdasarkan analisis teks yang sudah dilakukan, maka dapat disimpulkan bahwa fokus Amanat Agung adalah pemuridan. Pemuridan adalah suatu proses sengaja yang mana orang Kristen dewasa rohani memberitakan, mengajar, membimbing, mengarahkan dan membagi pengalaman-pengalaman kepada orang lain hingga orang-orang tersebut berkembang imannya dan mampu melakukan hal yang sama kepada orang lain lagi (Sembiring 2020). Kata $\mu \alpha \theta \eta \tau \varepsilon v ́ \sigma \alpha \tau \varepsilon$ merupakan padanan dari kata $\mu \alpha \theta \eta \tau \varepsilon \zeta$ yang umum diterjemahkan sebagai murid. Agaknya Matius memberikan perhatian khusus dengan kata ini terbukti dari jumlahnya yang cukup masif dalam kitab yakni \pm 40 kata (Darmawan 2019).

Anggapan bahwa pemuridan sama dengan pengajaran tidak sesuai dengan makna menjadikan murid pada Matius 28:19 ini. Kata kerja $\mu \alpha \theta \eta \tau \varepsilon v ́ \sigma \alpha \tau \varepsilon$ dimaksudkan lebih jauh dari sekadar pengajaran. Mengajar adalah salah satu 
BONAFIDE: Jurnal Teologi dan Pendidikan Kristen

www.jurnal.sttissiau.ac.id/Volume 2/Nomor 2/Desember 2021/hal.156-175

tahapan dalam proses pemuridan sedangkan proses pemuridan itu sendiri adalah rangkaian dari awal hingga akhir dari tahapan-tahapan yang sudah disampaikan oleh Yesus Kristus. Penjangkauan, pembaptisan dan pengajaran adalah bagian integral yang terdapat dalam proses pemuridan (Hull 2014).

Karena itu, aspek utama Amanat Agung adalah pemuridan bukan sekadar penginjilan atau pembaptisan atau bahkan pengajaran. Ketiganya wajib dilakukan secara integral dan komprehensif dalam rangka memuridkan seorang murid. Jika pemuridan menjadi goal dari petobat-petobat baru, maka kekristenan akan berdiri kuat di tengah-tengah dunia karena setiap orang yang menjadi Kristen sudah dilatih untuk menjadi seorang murid Kristus (Arifianto, Triposa, dan Lembongan 2020). Iman Kristen tidak pernah berdiri hanya di atas pengakuan diri melainkan komitmen dari masing-masing orang Kristen untuk tetap mengikuti teladan Yesus Kristus sebagai Gurunya (Hull 2014).

\section{Tahapan Pemuridan menurut Matius 28:19-20}

Tiga perintah yang ditulis dalam bentuk partisip (verb adjective) dimaknai sebagai kata kerja yang berfungsi sebagai kata sifat dan menjelaskan kata kerja utama (Sembiring 2020). Melalui pemahaman ini, penulis mengartikan ketiga kata kerja tersebut sebagai turunan dari kata kerja utama. Dengan kata lain, perintah pergilah, baptislah dan ajarlah merupakan tahapan yang dilakukan dalam konteks menjalankan perintah 'jadikanlah semua bangsa murid-Ku' (Hull 2014). Tiga tahapan itu dimulai dari perintah untuk pergi.

\section{Pergi Menjangkau Jiwa Baru}


BONAFIDE: Jurnal Teologi dan Pendidikan Kristen

www.jurnal.sttissiau.ac.id/Volume 2/Nomor 2/Desember 2021/hal.156-175

Para murid yang saat itu berada di bukit Galilea sedang getir dengan masa depan mereka. Bagaimana tidak, mereka harus siap mempertanggungjawabkan status mereka sebagai murid Kristus di hadapan orang-orang yang masih ragu atau bahkan terang terangan menolak Yesus. Status kemuridan harus dipertahankan dengan cara melakukan tugas murid. Pertama, mereka harus pergi. Mereka tidak boleh berdiam diri saja di Yerusalem, melainkan wajib menyebar ke Yudea,

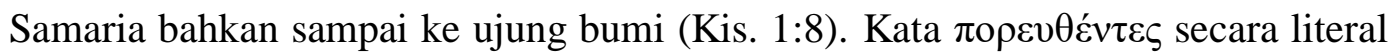
berarti 'pergi', tetapi maknanya biasa juga diterjemahkan sebagai meneruskan, hidup (Mounce 2011). Dalam konteks yang ada, tentu kata ini tidak diterjemahkan sebagai 'pergi' saja melainkan pergi dengan tujuan yang jelas yakni meneruskan, menghidupi Injil yang sudah diterima mereka dengan cara memberitakannya

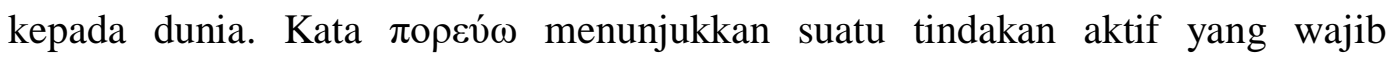
dilakukan oleh seorang murid yakni menjangkau orang-orang dengan Injil. Prinsip pemberitaan yang diinginkan Tuhan tidak boleh dilakukan dengan cara yang pasif melainkan aktif. Injil tidak perlu menunggu, Injil wajib menjangkau. Sebagai murid, orang Kristen perlu aktif menjangkau jiwa-jiwa yang belum mengenal Injil kebenaran. Keselamatan adalah berita baik yang wajib disiarkan bukan didiamkan. Injil memang dapat dibaca orang lain melalui perilaku sehari-hari murid, tetapi hal itu tidak menggeser pesan untuk aktif menjangkau orang lain. Jiwa-jiwa perlu dicari dan ditemukan sebagaimana Yesus mencari domba-dombaNya yang terhilang. Pemberitaan Injil adalah api kekristenan supaya genaplah firman Tuhan dalam Roma 10:15, "Betapa indahnya kedatangan mereka yang membawa kabar baik!" 
BONAFIDE: Jurnal Teologi dan Pendidikan Kristen

www.jurnal.sttissiau.ac.id/Volume 2/Nomor 2/Desember 2021/hal.156-175

\section{Baptis dalam Nama Bapa, Putra dan Roh Kudus}

Tahapan kedua dalam proses menjadikan seseorang murid Kristus adalah pembaptisan. Pembaptisan adalah tanda pertobatan seseorang (Mat. 3:11). Orang yang menerima Injil dan percaya pada Injil Yesus Kristus harus memberi diri untuk dibaptis sebagai deklarasi imannya. Diskusi pembaptisan ramai diperbincangkan dalam ranah teologi modern baik isu tentang tata cara pelaksanaan maupun pengaruhnya dalam keselamatan seseorang. Namun, hal ini tidak dibahas dalam artikel karena fokus penelitian lebih kepada baptisan dalam rangkaian pemuridan.

Alkitab memberi beberapa contoh proses penjangkauan yang ditindaklanjuti dengan proses baptisan (Bdk. Mrk. 16; Luk. 3; Kis. 8, 19). Baptisan penting dilakukan oleh para murid yang sudah menginjili petobatpetobat baru sebagai materai dan tanda komitmen mereka untuk mengikuti Allah dengan sungguh. Esensi dan pengesahan baptisan bukan terletak pada tata cara pembaptisannya melainkan kualitas ilahi yang menaunginya. Dalam nama Bapa,

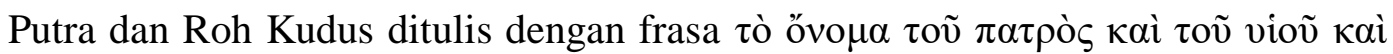

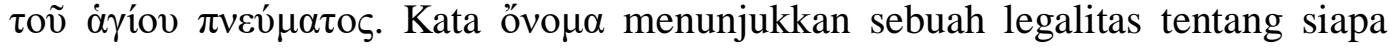
yang mengesahkan baptisan tersebut. Terjemahan kata vios dalam LAI adalah Anak, tetapi kata ini lebih jelas diterjemahkan sebagai Putra, pribadi kedua Allah yakni Tuhan Yesus Kristus. Kata penghubung kaì dipakai untuk memisahkan masing-masing pribadi Allah. Allah Tritunggal-lah mengesahkan baptisan orang percaya. Dengan baptisan, murid mendeklarasikan komitmennya dan Allah mendeklarasikan kepemilikan-Nya atas orang yang dibaptis tersebut. Dengan 
BONAFIDE: Jurnal Teologi dan Pendidikan Kristen

www.jurnal.sttissiau.ac.id/Volume 2/Nomor 2/Desember 2021/hal.156-175

demikian, seorang yang sudah memberi diri untuk dibaptis telah dinyatakan milik Allah sepenuhnya. Sebagai milik Allah, hidupnya kini dan selanjutnya adalah untuk kemuliaan nama Allah. Manusia baru yang siap dimuridkan tampil sebagai pribadi yang dibenarkan, dikuduskan dan dilayakkan Tuhan dan siap menTuhankan Dia dalam setiap aspek kehidupan nyatanya (Tumanan 2008). Sebagai warga Kerajaan Sorga, murid mempunyai misi untuk meneruskan Amanat Agung Yesus Kristus di dunia ini.

\section{Ajar Mereka untuk Melakukan Segala Sesuatu yang Diperintahkan Tuhan}

Proses pengajaran merupakan tahapan akhir dalam pemuridan. Seorang murid yang berkomitmen untuk mengikuti teladan Sang Guru tentu akan berkomitmen untuk memahami segala sesuatu yang diajarkan-Nya. Pengajaran dalam konteks Matius 28:19-20 merujuk pada kebenaran yang sudah diterima dari Yesus Kristus (Belo 2019). Kebenaran Injil itu berisi tentang hal-hal yang berkenan bagi Tuhan, pemahaman yang benar akan hukum Tuhan dan segala yang dikehendaki Tuhan, itulah yang wajib diajarkan supaya dilakukan (Belo 2019).

Segala kebenaran sudah diberikan untuk semua orang percaya masa kini di dalam Firman Tuhan yakni Alkitab. Pengajaran diberikan dalam komunitas bertumbuh bersama baik di gereja, sekolah, keluarga maupun persekutuan orang percaya. Gereja wajib menyiarkan pengajaran yang berpusat pada Firman Kebenaran dan sekolah khususnya konteks Pendidikan Agama Kristen juga memberikan pengajaran kepada para murid Kristen (Laia 2020). Pengajaran Pendidikan Agama Kristen yang memuridkan akan mendorong pertumbuhan iman seorang murid menjadi lebih dewasa dan terus belajar dari pengalaman- 
BONAFIDE: Jurnal Teologi dan Pendidikan Kristen

www.jurnal.sttissiau.ac.id/Volume 2/Nomor 2/Desember 2021/hal.156-175

pengalaman orang Kristen yang sudah dewasa (Sembiring 2020). Karena itu, semua komunitas rohani wajib memaksimalkan pemuridan sebagai metode untuk meningkatkan kualitas iman para murid Kristus.

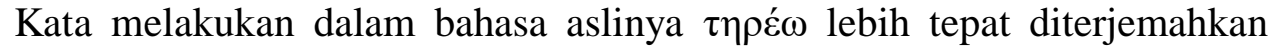

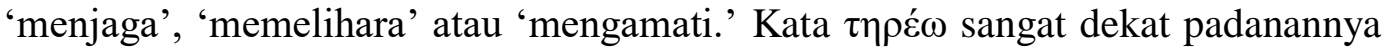

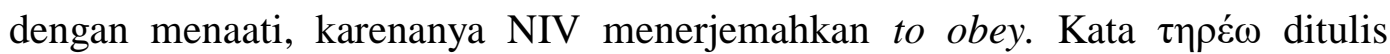
dalam bentuk infinitive present active. Kata kerja infinitive present active menyatakan tindakan kontinu yang menjelaskan tujuan tertentu (Mounce 2011). Murid Kristus wajib memusatkan perhatiannya kepada semua yang sudah diperintahkan Guru supaya mereka melakukannya. Semua yang diajarkan oleh Yesus Kristus wajib dilakukan oleh murid-murid-Nya. Injil tidak pernah sempurna dalam teori melainkan adalah aksi nyata. Apa yang diperintahkan Sang guru wajib dipelihara, dipegang teguh dan diaplikasikan dalam kehidupan nyata seorang murid. Sampai di tahap inilah, seseorang benar-benar sudah menjadi seorang murid Kristus.

\section{Janji Penyertaan dalam Implementasi Amanat Agung}

Sebagai penutup deklarasi Amanat Agung, Yesus juga memberikan janji penyertaan kepada semua murid-Nya (Pfeiffer dan Harrison 2013). Ia tidak berhenti sampai di deklarasi saja, melainkan memberikan janji penyertaan kepada

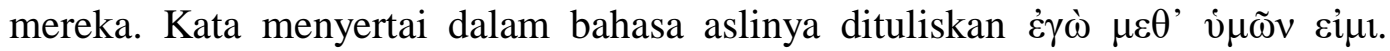
Frasa $\dot{\varepsilon} \gamma \grave{\omega} \mu \varepsilon \theta$ ' $\dot{v} \mu \tilde{\omega} \nu$ berarti 'aku bersama kamu sekalian.' Kata $\varepsilon i j \mu$ berarti 'aku adalah' ditulis dalam bentuk verb indicative present. Kala present memiliki aspek terus menerus atau sesuatu yang dikerjakan secara kontinu (Mounce 2011). Kata 
BONAFIDE: Jurnal Teologi dan Pendidikan Kristen

www.jurnal.sttissiau.ac.id/Volume 2/Nomor 2/Desember 2021/hal.156-175

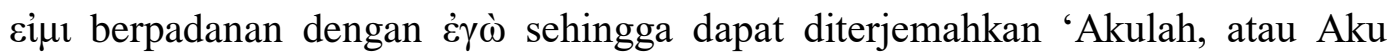
sendiri', sebuah penegasan untuk Subjek. Dengan demikian, frasa ini diterjemahkan "Akulah terus menerus bersama kalian." Ia menyertai karena Ia selalu bersama pada murid. Sekalipun dalam kasat mata -pada waktu itu- Ia segera naik ke Sorga tetapi eksistensi-Nya tidak dibatasi ruang dan waktu. Ia, Sang Immanuel selalu menyertai murid-murid-Nya.

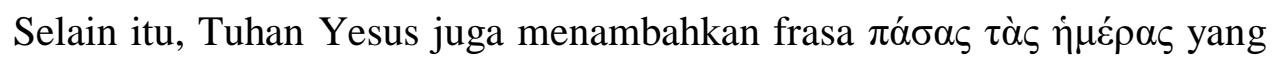

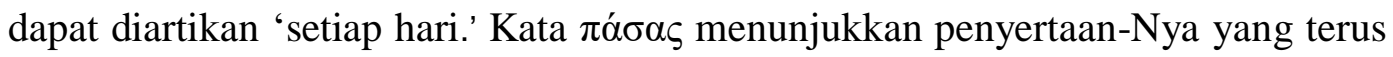
menerus berkesinambungan. Penyertaan-Nya setiap hari sampai menuju kepada

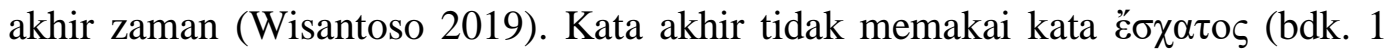

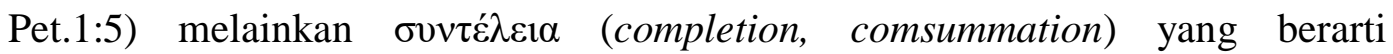
'penyelesaian' atau 'penyempurnaan.' Artinya, Tuhan Yesus sudah menyatakan bahwa akan tiba waktu/zaman penyempurnaan dari segala pengharapan seorang murid (Dwiraharjo 2019). Akhir zaman bukanlah akhir segalanya, justru merupakan zaman kesempurnaan yang akan menjadi masa kekal umat dengan Allah. Sampai pada waktu itulah, Ia tetap menyertai para murid yang terus berjuang melaksanakan Amanat Agung-Nya. Berdasarkan analisis kata-kata di atas, janji penyertaan Tuhan Yesus ini dapat diterjemahkan demikian, "Dan ketahuilah, Aku sendiri (Tuhan Yesus) terus menerus bersama kamu sekalian setiap hari sampai pada waktu penyempurnaan itu" (Nainggolan 2014).

Dengan demikian setiap murid Kristus yang melakukan pemuridan kepada orang-orang di seluruh dunia ini sebagai bentuk implementasi Amanat Agung pasti mendapatkan janji penyertaan setiap harinya dari Sang Pemberi Mandat 
BONAFIDE: Jurnal Teologi dan Pendidikan Kristen

www.jurnal.sttissiau.ac.id/Volume 2/Nomor 2/Desember 2021/hal.156-175

yakni Tuhan Yesus Kristus sendiri sampai pada zaman penyempurnaan itu (Dwiraharjo 2019). Ia sekali-kali tidak akan meninggalkan murid-murid-Nya karena Ia adalah Imanuel (Gandaputra 2021). Sungguh, sebuah kata kepastian yang menghiburkan!

\section{KESIMPULAN}

Pemuridan adalah aspek utama dalam implementasi Amanat Agung dari Tuhan Yesus Kristus. Mengabaikan aspek pemuridan dengan cara tidak memfollow up jiwa-jiwa yang sudah diinjili merupakan kelalaian dalam implementasi Amanat Agung tersebut. Petobat-petobat baru wajib dimuridkan supaya mereka menjadi murid Kristus yang sejati. Matius 28:19-20 menjelaskan tahapan-tahapan yang dapat dilakukan dalam implementasi Amanat Agung yakni: pergi menjangkau jiwa, membaptis mereka dan mengajarkan segala sesuatu yang diperintahkan Tuhan Yesus Kristus. Dalam lingkup perintah untuk menjadikan seluruh bangsa murid Yesus Kristuslah, maka ada perintah-perintah lain sebagai tahapan pemuridan yakni pergi untuk memberitakan (penginjilan), membaptis orang-orang yang baru percaya dalam nama Bapa, Putra dan Roh Kudus, serta mengajarkan mereka untuk melakukan segala perintah yang diberikan Yesus Kristus. Akhirnya, sebuah closing statement dalam kitab Injil pertama ini memberikan sebuah jaminan kepada para murid Kristus bahwa Ia sendiri menyertai para murid senantiasa sampai kepada akhir zaman (Mat. 28:20). 
BONAFIDE: Jurnal Teologi dan Pendidikan Kristen

www.jurnal.sttissiau.ac.id/Volume 2/Nomor 2/Desember 2021/hal.156-175

\section{DAFTAR PUSTAKA}

Arifianto, Yonatan Alex, Reni Triposa, dan Paulus Karaeng Lembongan. 2020. "Bible Study of Mission and Discipleship in the Great Commission and Its Implications for Today's Christian Life.” Diegesis: Jurnal Teologi 5 (2): 2542. https://doi.org/10.46933/dgs.vol5i225-42.

Belo, Yosia. 2019. "Pendidikan Agama Kristen Dalam Matius 28:19-20.” Jurnal Luxnos 5 (2): 127-33. https://doi.org/10.47304/jl.v5i2.21.

Darmawan, I Putu Ayub. 2019. "Jadikanlah Murid: Tugas Pemuridan Gereja Menurut Matius 28:18-20." Evangelikal: Jurnal Teologi Injili dan Pembinaan Warga Jemaat 3 (2): 144. https://doi.org/10.46445/ejti.v3i2.138.

Dwiraharjo, Susanto. 2019. "Kajian Eksegetikal Amanat Agung menurut Matius 28:18-20." Jurnal Teologi Gracia Deo 1 (2): 56-73. https://doi.org/10.46929/graciadeo.v1i2.8.

Gandaputra, Edwin. 2021. "Memikirkan Ulang Aplikasi Penginjilan Pribadi Pada Masa New Normal” 1 (1): 29-45.

Gunawan, Agung. 2020. "Pemuridan Dan Kedewasaan Rohani." SOLA GRATIA: Jurnal Teologi Biblika dan Praktika 5 (1): 1-17. https://doi.org/10.47596/solagratia.v5i1.52.

Hull, Bill. 2014. Panduan Lengkap Pemuridan: Menjadi dan Menjadikan Murid Kristus. Surabaya: Katalis Media dan Literatur Yayasan Gloria.

Hutagalung, Patrecia. 2020. "Pemuridan Sebagai Mandat Misi Menurut Matius 28 : 18-20 Discipleship As a Mandate of Mission According To Matthew 28 : 18-20." Pengarah: Jurnal Teologi Kristen 2 (1): 64-76.

Laia, Oinike. 2020. "Model Pemuridan yang Relevan untuk Pelayanan Pendidikan Kristen." The New Perspective in Theology and Religious Studies 1 (1): 3554. https://doi.org/10.47900/nptrs.v1i1.3.

Mounce, William D. 2011. Basic Of Biblical Greek: Dasar-dasar Bahasa Yunani Biblika. Malang: Literatur SAAT.

Nainggolan, B. 2014. "Konsep Amanat Agung Berdasarkan Matius 28:1820 Dalam Misi.” Jurnal Koinonia 8 (2): 15-45.

Pfeiffer, Charles F., dan Everett Harrison. 2013. The Wycliffe Bible Commentary. Malang: Gandum Mas.

Sembiring, Johannes. 2020. "Implementasi Pola Pemuridan Yesus Menurut Injil Matius." KHARISMATA: Jurnal Teologi Pantekosta 2 (2): 113-26. https://doi.org/10.47167/kharis.v2i2.34.

Situmorang, Jonar. 2014. Sejarah Gereja Umum. Yogyakarta: Penerbit ANDI. 
BONAFIDE: Jurnal Teologi dan Pendidikan Kristen

www.jurnal.sttissiau.ac.id/Volume 2/Nomor 2/Desember 2021/hal.156-175

2021. Ekklesiologi: Gereja yang Kelihatan dan Tak Kelihatan. Yogyakarta: Penerbit ANDI.

Surya, Agus, dan Setinawati Setinawati. 2021. "Pemikiran diskursif amanat agung Injil Matius 28:18-20." Kurios $7 \quad$ (1): 42. https://doi.org/10.30995/kur.v7i1.242.

Tenney, Merrill C. 2009. Survey Perjanjian Baru. 9 ed. Malang: Gandum Mas.

Tjia, Johnny, Barry van der Schoot, dan Irwan Tjulianto, ed. 2008. Tafsiran Matthew Henry: Injil Matius 15:28. Surabaya: Momentum.

Tumanan, Perdian K. M. 2008. "Kerajaan Imam : Teologi Kerajaan Allah dan Implikasinya bagi Pemuridan Kristen Masa Kini." Veritas: Jurnal Teologi dan Pelayanan 9 (2): 153-71. https://doi.org/10.36421/veritas.v9i2.198.

Wisantoso, Sandra. 2019. "Korelasi Konsep Kerajaan Allah dan Pemuridan dalam Injil Matius bagi Pemuridan Masa Kini." Veritas: Jurnal Teologi dan Pelayanan 18 (1): 45-67. https://doi.org/10.36421/veritas.v18i1.323.

Yen, Edwin Gandaputra. 2019. "Tinjauan Ulang Penginjilan Pribadi dalam Kerangka Amanat Agung Tuhan Yesus Melalui Eksposisi Matius 28: 19-20.” Jurnal Efata 5 (1): 1-17. 